\title{
The Impact of Corporate Social Responsibility and Internal Marketing on Employee Turnover Intentions with the Mediating Role of Organizational Commitment
}

\author{
Hasan Boudlaie \\ Member of University of Tehran, kish international campus, Tehran, Iran \\ hasanboudlaie@ut.ac.ir
}

Behrouz Keshavarz Nik

M.A. in executive Management, Kish International Campus, University of Tehran, Tehran, Iran

Behrooz.nik85@gmail.com

Mohammadhosein Kenarroodi

$\mathrm{PhD}$ candidate, Department of Social and Behavioral Sciences, Kish International Campus, University of Tehran, Tehran, Iran

\begin{abstract}
Employee turnover is one of the most important phenomena in the study of individuals' organizational behavior. For this reason, organizations able to identify effective factors in employee turnover are more likely to employ more effective policies and methods to maintain their human resources before they leave the organization. This study aims to investigate the impact of corporate social responsibility and internal marketing on employee turnover intentions, considering the mediating role of organizational commitment. The present research is practical in purpose, descriptive in data collection methodology and a survey research in type. The research population consisted of all employees in all Tehran branches of the Melli Bank of Iran, amounting to 9405 people. The Cochran formula was used to determine the sample size, which yielded a sample size of 369 people. This research employs the clustering method for sampling and a standard survey for data collection. The statistical method utilized in this study is the structural equation method and all statistical analysis was performed using SPSS19 and AMOS23 softwares. Testing the research hypotheses revealed that social responsibility and internal marketing have a positive and significant effect on organizational commitment and organizational commitment has a significant negative impact on employee turnover intentions. Also, organizational commitment completely mediates the negative impact of social responsibility and internal marketing on the employee turnover intentions.
\end{abstract}

Keywords. social responsibility, internal marketing, organizational commitment, turnover intention 


\section{Introduction}

Employee turnover is one of the most important phenomena in the study of individuals' behavior in organizational environments. Nowadays, it has become one of the most important concerns of human resource managers. Organizations are always apprehensive of losing their human capital and sustaining a damage, because every organization undergoes lots of expenditures to teach, train and prepare their employees up to the stage of optimal productivity and efficiency; and by losing valuable workforces, organization suffers from the loss of skills and experiences achieved over many years of (Hom, Griffeth, 1995). Since employees are introduced as one of the critical parameters in the process of creating value throughout service organizations, the role of loyal and committed employees is very important in making the customers loyal. Different factors affect employees' turnovers, one of which is organizational commitment (OC). Organizational commitment is also considered as one of the most important factors affecting productivity and continued presence of individuals in organizations (O'Reilly, 1989). Therefore, ensuring organizational commitment is one of the best methods for attracting and maintaining talented employees as well as gaining better performance for organizations. Organizational commitment itself is influenced by several factors; and paying attention to the factors that affect organizational commitment can in turn affect employees' turnover desire.

Nowadays, the two concepts of social responsibility and internal marketing (IM) are new concepts noticed by organizations, especially among service organizations, and research have shown that social responsibility is one of the ways by which managers can increase their employees' commitment (Hui, Rousseau, 2004). Corporate social responsibility (CSR) is a concept of growing interest; moreover, most organizations have started to increase their efforts in order to invest in social responsibility plans (Dennis, 1995). However, the concept of CSR has been discussed and investigated by management and marketing researchers with a more serious approach since early 1960 s in particular, in the first decade of $21^{\text {st }}$ century its meaning has changed in comparison to the last decade of the $20^{\text {th }}$ century. Currently, it refers to a set of activities that investors and economic enterprise owners voluntarily perform as effective and useful members of the society (Hogg, Carter, 2000). On the other hand, in the existing competitive environment, success requires adaptation of IM approaches, plans and programs by organizations more than ever (Rafiq, Ahmed, 2000). Internal marketing is defined as training, encouraging, and paying employees, so that the organization can successfully provide good customer service. IM plans can contribute to employee organizational commitment, which in turn has a significant impact on job satisfaction, job performance, and desire to turnover [social responsibility] (Cotton, Tuttle, 1986). Therefore, the notion supporting IM programs is that employees are treated as internal customers and tasks are considered as products. The task that each business employee is required to complete is considered as an internal product; besides, work products must encourage, foster, and attract employees (Caruana, Calleya, 1998).

In recent years, the expansion of private banks activities in Iran as real competitors of Melli Bank alongside with growing expectations appeared in the society, government and other stakeholders from Melli Bank to provide better and more efficient services has forced this bank to consider and implement important improvement plans in different areas in order to overcome intensive competitions and challenges ahead. In this regard, the importance of paying attention to human resources in Melli Bank has become more apparent. Hence, considering the importance of social responsibility and internal marketing in organizations and since no previous research has addressed the simultaneous effects of social responsibility and internal marketing on organizational commitment and turnovers in Melli banks of Tehran, 
the current study examines the effects of four aspects of CSR (including economic, legal, ethical and philanthropic responsibilities) and five aspects of IM (including welfare system, training, salary and benefits, communications, and management support) on the employees turnover intentions considering the mediating role of organizational commitment.

\section{Theoretical Foundations}

\subsection{Employee Turnover}

Turnover intention implies that employees are not willing to stay at their current jobs (MacLagan, 1999). Bluedorn (1978) has provided two distinct definitions (i.e. general and specific) for the functional aspect of turnover. In general definition, turnover is leaving an organization and expressing dissatisfaction with the current job (Bluedorn, 1978). In specific definition, turnover is expressed as a change in an individual's membership within an organization which involves a wide range of relocations and status changes (Kotler, Lee, 2005). Turnover intention is defined as the extent to which a person moves toward the external range of membership in a social system which is initiated by the individual themself. Unlike actual turnovers, turnover intentions are not obvious. Intention is the expression of beliefs about a particular behavior of interest. Turnover intentions is defined as thinking about the mental possibility of the fact that a person will change their job during a certain period of time, which is one of the main prerequisites of actual turnover. Results gathered from different studies provide evidence for the great importance of turnover intentions when investigating about individual turnover behavior. An individual's turnover intention results in paying attention to and evaluating various job options (Holmes, Watts, 2000). Turnover intention is an individual's perception toward turnover; although, he/she is currently staying in their job position. Turnover intention conveys the same meaning as anticipated turnover, i.e. the possibility of an individual leaving a job position. Anticipated turnover is defined as the degree to which a person thinks or believes he will voluntarily leave his current job position (Prutina, 2016).

Costs caused by employees' withdrawal from an organization are divided into two categories.

(A) Direct costs which include:

1. Difference in the cost of recruiting a new employee and the total amount paid to a withdrawn employee.

2. The total cost associated with finding a new employee, including knowledge and selection process.

3. Costs that will be spent on training a new employee.

4. Costs that are spent on socialization process of a new employee including costs associated with additional efforts of supervisors and coworkers to coordinate and integrate the new employee.

(B) Indirect costs which include:

1. Paying overtime to non-exempt employees within organization or paying salaries and benefits to new employees who are replacing withdrawn ones from outside.

2. The financial value of production losses or the lack of customer satisfaction resulting from failure or negligence to deliver products or services according to the schedule, which directly leads to dysfunctional turnover and these losses continue to occur until the organization finds a new replacement who starts working at the same level as the previous employee.

3. Other indirect costs of turnover are the possible negative effects on employees' morale which may even result in turnover of other individuals (Ramos, 2015). 


\subsection{Organizational Commitment}

Organizational commitment is one of the most important research topics which contains many theoretical indications for organizations. Without doubt, all existing organizations in the world are looking for employees who are committed to their organization and its goals. Organizational commitment, as an important dimension of job attitude, is a psychological identity that each person feels toward their followed organization Vakola, (Nikolaou, 2005). According to O'Reilly (1989), organizational commitment is "an individual's psychological bond to the organization, including a sense of job involvement, loyalty, and belief in the values of the organization" (Peterson, 2004). Despite having numerous differences, several concepts such as conscience, work ethic, willingness, and responsibility are used as equivalents to "commitment", in other words, commitment has been defined in different ways like many other concepts of organizational psychology (Prutina, 2016). Organizational commitment refers to the positive or negative attitudes of individuals towards the entire organization (not the job) they work with. In organizational commitment, an individual has a strong sense of loyalty to the organization and identifies themself through the organization (Kim, Lee, 2016).

The two views currently proposed concerning organizational commitment are as follows:

1. Affective (attitudinal) commitment: The first viewpoint regards organizational commitment as an affective (or attitudinal) matter; emotional commitment can be placed in this category. According to this view, individuals identify themselves with regard to the organization; therefore, they continue to be members of the organization to achieve goals.

2. Behavioral Commitment: The second viewpoint is derived from researches of Baker who considers commitment as a behavioral matter rather than an attitudinal one. According to this view, individuals depend on the organization to obtain advantages such as benefits and seniority rather than having any positive affections and emotions toward the organization. In the attitudinal viewpoint, researches have mainly oriented toward identifying the factors causing commitment, as well as the consequences and results of commitment. However, in the behavioral viewpoint, researches are primarily focused on identification of the effects of such a behavior on changes in attitude. It should be noted that in the study of organizational commitment, these two viewpoints should not be considered as opposing one another. In fact, the proper recognition of the process of attachment and affiliation to the organization can be achieved by simultaneous examination of attitudinal and behavioral commitment. These two viewpoints are favorable regarding general principles; however, behavioral viewpoint provides a more vivid image of organizational commitment in the behavior of an individual. Thus, according to these two views, managers should try to govern dynamic relationships among employees' behaviors which requires continuous training of employees to reduce resistance against the necessary changes in the organization. Training makes attitudes and behaviors more dynamic and defrosts the behavior of an individual (Kim, Lee, 2016).

\subsection{Internal Marketing}

Berry (1981) first introduced the concept of IM in the 1980s. A fact related to the concept of IM is that employees form the internal market within an organization, i.e. the organization has an internal market with internal customers and suppliers and meeting the needs of these internal customers is necessary to the success of the organization (Varey, 1995). Internal marketing responds to the importance of human capital in organizations since 
it is presented as a management philosophy that contributes to the development of strategies and plans to motivate managers to encourage, attract, and promote employees' performances, which in turn results in achievement of organizational goals regarding final customers in the foreign market (Ismail, Sheriff, 2017). Internal marketing focuses on the proper internal relationships among individuals at all levels in organizations; thus, a service-oriented and customer-oriented approach is formed among employees when interacting with customers. Internal marketing acts as a comprehensive managerial process which combines and integrates multiple tasks of organizations in two directions. Firstly, internal marketing makes all employees at all levels of the organizations, businesses, and activities to understand and experience different processes in the context of a given environment. Secondly, it helps all employees to get prepared and motivated to operate in a service-oriented manner (Martinez, Guzman, Carrilo, 2017). Dennis (1995) observes internal marketing as a kind of strategic management philosophy that contributes to attracting, developing, motivating and maintaining important and outstanding employees by providing a high-quality work environment and meeting their needs (Dennis, 1995). Internal marketing as a kind of management technology attempts to solve problems related to internal service productivity, market orientation, successful implementation of appropriate plans and customer orientation (Varey, Lewis, 1991). Hogg \& Carter (2000) define internal marketing as an inseparable part of market orientation which requires the use of marketing techniques within an organization in order to create and communicate company values. Rafiq and Ahmad (2000) presented one of the most comprehensive definitions of internal marketing: "a planned effort using a marketing-like approach to overcome organizational resistance to change and to align, motivate and inter-functionally coordinate and integrate employees towards the effective implementation of corporate and functional strategies in order to deliver customer satisfaction through a process of creating motivated and customer-orientated employees" (Rafiq, Ahmad, 2000).

The five aspects of internal marketing are: 1) welfare systems; 2) training; 3) benefits and rewards; 4) communications; and 5) management support (Kim, Lee, 2016).

\subsection{Social Responsibility}

Humans are social beings who live in societies from birth to death and are constantly interacting with one another. One must continuously learn how to live in a community and meet his/her own needs. This requires a series of social skills that an individual learns through a socialization process, and proper learning of these skills can result in formation of social responsibility (Berman, 1993). In the early 1950s, Howard Boone defined social responsibility as business commitments to pursue decisions and policies that are desirable in terms of our society's goals and values (Mensah, Neurtey, 2017). Organizational social responsibility is a form of management that includes ethical relationships and a crystal clear interaction with all stakeholders of the organization and its establishment as a part of the organization's goals can create the potential to adapt with sustainable development of society to preserve cultural and environmental resources. It is able to reduce social issues of future generations by creating diversity and improvement. Social responsibility is also defined as "following social laws and meeting the expectations of a society from individuals". These rules are inferred from social roles. In fact, they express cultural and social norms and indicate how and to what extent individuals show commitment and obligation toward other individuals in the society (Ford, 1985). The trend of recent businesses confirms that organizations are expected to act beyond a profit-oriented strategy and put community welfare in the first priority. Social responsibility advocates argue that large organizations need to develop social 
responsibility as a strategic key in organizations not only to meet the needs of stakeholders but also to meet the needs of different communities in the society, including customers, suppliers, and employees. In terms of work ethics, most efforts have been made to distinguish between different types of responsibilities. To do so, a clear attitude must be shaped regarding the concept of responsibility. Responsibility often refers to a kind of relationship between individuals and their surrounding environment. In the context of responsibility, one's attitude toward their actions also forms a part of their response, and this response might be questioned (Fisscher, Nijhof, 2005). McLagan (1998) considers CSR as a process in which managers take responsibility for identifying, adapting, and matching to the interests of groups that are affected by the organization's activities. Kotler and Lee (2005) defined CSR as a commitment to improving community well-being through discretionary business practices and corporate resource contributions. Holmes and Watts (2000) defined CSR as the business unit's commitment to contribute to sustainable economic development through working with employees, their families, the local community, and society at large to improve the quality of life.

Carroll (1991), defined the social responsibilities of each firm in four dimensions of economic responsibility (Lantos, 2001), legal liability, ethical responsibility (Jamali, Mirshak, 2006), and philanthropic responsibility (Sheth, 2006). Different types of responsibility are shown in Figure 1.

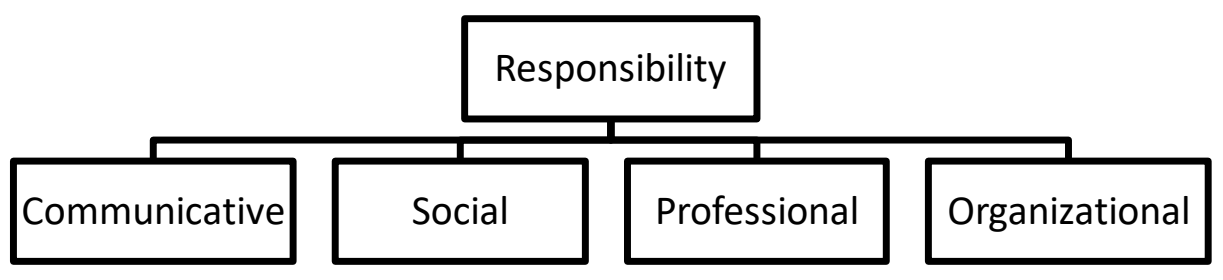

Figure 1. Types of Responsibility (Gilligan, 1982).

\subsection{Research background}

Kim et al. (2016), conducted a research entitled as "effects of corporate social responsibility and internal marketing on organizational commitment and turnover intentions" using a questionnaire distributed among 310 employees of a casino company. The authors found that employees' perceptions of social responsibility and internal marketing are positively related to their organizational commitment and negatively to their turnover and relocating intentions (Kim, Lee, 2016). In another research by Prutina (2016) entitled as "the effect of corporate social responsibility on organizational commitment", data was collected by distributing a questionnaire among 196 employees of a multinational company in Bosnia and Herzegovina. Prutina (2016) found that employees' perception of social responsibility affects organizational commitment. In Ramos's (2015) study on "internal marketing dimensions and organizational commitment of Universal Banks' employees", questionnaires were distributed among 43 employees of Universal Bank in Philippines. The author found that job satisfaction along with understanding and differentiation were significantly correlated to organizational commitment (Ramos, 2015).

\section{Conceptual Model and Research Hypotheses}

The conceptual model of this research which is based on the presented theoretical foundation is shown in Figure 2. 


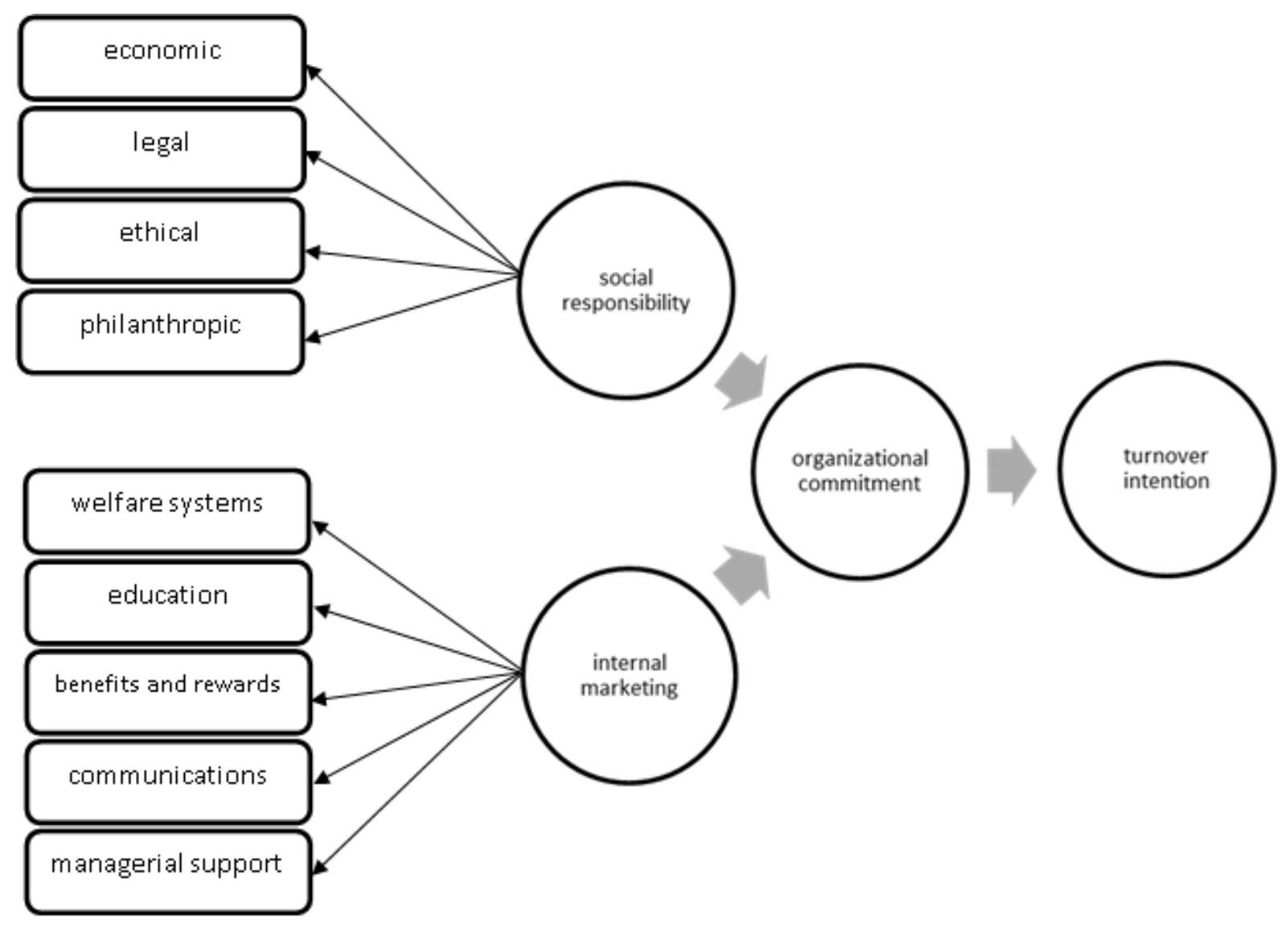

Figure 2. Conceptual model of the study (Kim, Lee, 2016).

As can be seen in Figure 2, the research hypotheses are:

$\mathrm{H}_{1}$ : Social responsibility has a positive and significant effect on organizational commitment. commitment.

$\mathrm{H}_{2}$ : Internal marketing has a positive and significant impact on organizational

$\mathrm{H}_{3}$ : Organizational commitment has a negative and significant effect on employees' turnover intention.

$\mathrm{H}_{4}$ : Organizational commitment has a mediating role regarding the effect of social responsibility on employees' turnover intention.

$\mathrm{H}_{5}$ : Organizational commitment has a mediating role regarding the effect of internal marketing on employees' turnover intention.

\section{Research Methodology}

The current study is an applied research regarding study objectives and has a descriptive survey methodology regarding data collection procedure.

In this research, the statistical population includes all employees of Melli Bank branches in Tehran, i.e. a total number of 9405 employees. Sample size was calculated using the Cochran's formula which was equal to 369 people and a cluster sampling type was used. In the bank branches located in east, west, center, south and north of Tehran, a total of 450 questionnaires were distributed. A number of 370 questionnaires were returned among which 
58 questionnaires were excluded from the analysis due to large amount of missing data. Finally, 312 questionnaires were examined.

To collect data, a standard questionnaire by Kim et al. (2016), was used which consists of 41 questions and is designed based on a continuum 5-point Likert scale (i.e. from strongly disagree to strongly agree). A number of 13 questions were intended to measure the variable of organizational social responsibility which assess social responsibility in accordance with its four dimensions: economic (3 questions); legal (4 questions), ethical (2 questions), and philanthropic (4 questions). A number of 16 questions were designed to measure the variable of organizational internal marketing in accordance with its five dimensions: education (3 questions), communication (3 questions), welfare systems (4 questions), benefits and rewards (3 questions), and managerial support (3 questions). A number of 7 questions focused on measuring the variable of organizational commitment and the remaining 5 questions were to measure the variable of turnover intention.

To calculate the reliability of the study, Cronbach's alpha coefficient $(\alpha)$ was used. The results were equal to $\alpha<0.7$ for all research variables, indicating a good reliability of the questionnaire items. The results of Cronbach's alpha coefficient calculations are shown in Table 1.

Table 1. Cronbach's alpha coefficient of questionnaire variables

\begin{tabular}{lccc}
\hline Variables & $\begin{array}{l}\text { Number } \\
\text { Questions }\end{array}$ & $\begin{array}{c}\text { of } \\
\text { Cronbach's } \\
\text { coefficient }\end{array}$ & alpha \\
\hline social responsibility & 13 & $\alpha=0.889$ & \\
\hline internal marketing & 16 & $\alpha=0.947$ & \\
\hline $\begin{array}{l}\text { organizational } \\
\text { commitment }\end{array}$ & 7 & $\alpha=0.918$ \\
\hline turnover & 5 & $\alpha=0.900$ \\
\hline the entire questionnaire & 41 & $\alpha=0.931$ \\
\hline
\end{tabular}

The research validity was calculated using a confirmatory factor analysis (CFA). The results of confirmatory factor analysis and model's goodness-of-fit indices are shown in Table 2. Chi-squared index is one of the most important indices and as it can be seen in Table 2., chi-squared index is within the acceptable range for all variables. Since all of abovementioned variables for social responsibility, internal marketing, organizational commitment and turnover variables are within an acceptable range, it can be concluded that there is a goodness-of-fit for models which is created by data.

Table 2. Results of confirmatory factor analysis for each item in the questionnaire

\begin{tabular}{|l|c|c|c|c|c|c|c|c|c|}
\hline & CMIN/DF & GFI & AGFI & NFI & RFI & IFI & TLI & RMSEA & CFI \\
\hline $\begin{array}{l}\text { social } \\
\text { responsibility }\end{array}$ & 2.084 & 0.946 & 0.913 & 0.932 & 0.905 & 0.963 & 0.948 & 0.059 & 0.963 \\
\hline $\begin{array}{l}\text { internal } \\
\text { marketing }\end{array}$ & 2.091 & 0.930 & 0.895 & 0.946 & 0.929 & 0.917 & 0.962 & 0.059 & 0.971 \\
\hline $\begin{array}{l}\text { organizational } \\
\text { commitment }\end{array}$ & 2.741 & 0.947 & 0.933 & 0.980 & 0.962 & 0.987 & 0.975 & 0.075 & 0.987 \\
\hline turnover & 0.922 & 0.995 & 0.983 & 0.996 & 0.990 & 1 & 1 & 0.00 & 1 \\
\hline $\begin{array}{l}\text { acceptable } \\
\text { range }\end{array}$ & $<3$ & $>0.9$ & $>0.8$ & $>0.9$ & $>0.9$ & $>0.9$ & $>0.9$ & $<0.08$ & $>0.9$ \\
\hline
\end{tabular}




\section{Results}

In order to analyze the data, the author(s) first used descriptive statistics, tables, and figures. In the next step, to verify models' goodness-of-fit obtained from confirmatory factor analysis method and to test the hypotheses, we applied structural equation modeling (SEM) and path analysis in particular, using $\mathrm{SPSS}_{19}$ and $\mathrm{AMOS}_{23}$ softwares.

\subsection{Descriptive Statistics}

In terms of descriptive statistics, $75.1 \%$ of respondents were male; $47 \%$ held bachelor's degrees, 43.8\% held associate's degrees, 5.4\% held master's degrees or higher, and the remaining $3.5 \%$ of respondents held diploma degrees or lower. In terms of age range, $47.9 \%$ of respondents were between 40 to 50 years old, $17.6 \%$ were between 30 to 40 years old, $19.8 \%$ were less than 30 years old, and the rest were over 50 years old. In terms of work experience, $33.9 \%$ had over 20 years' experience, $35.8 \%$ had 20 to 15 years' experience, $22 \%$ had 15 to 10 years' experience, and $8 \%$ had less than 10 years' experience.

\subsection{Inferential statistics}

In order to calculate goodness of fit and analyze the general model of structural equations, a second order confirmatory factor analysis was used. When at least three values of goodness-of-fit indices are desirable, one can claim that goodness-of-fit is acceptable. According to the results of Table 3., since all mentioned indices are within an acceptable range; therefore, the general model of structural equations is well-fitted. Moreover, the standard regression coefficients related to the general model of structural equations are shown in Figure 3.

Table 3. Goodness-of-fit indices related to the general model of structural equations

\begin{tabular}{|l|l|l|l|l|l|l|}
\hline & CMIN/SF & IFI & PCFI & TLI & RMSEA & CFI \\
\hline $\begin{array}{l}\text { General } \\
\text { Model }\end{array}$ & 1.950 & 0.914 & 0.843 & 0.906 & 0.055 & 0.913 \\
\hline $\begin{array}{l}\text { Acceptable } \\
\text { Range }\end{array}$ & $<3$ & $>0.9$ & $>0.5$ & $>0.9$ & $<0.08$ & $>0.9$ \\
\hline
\end{tabular}




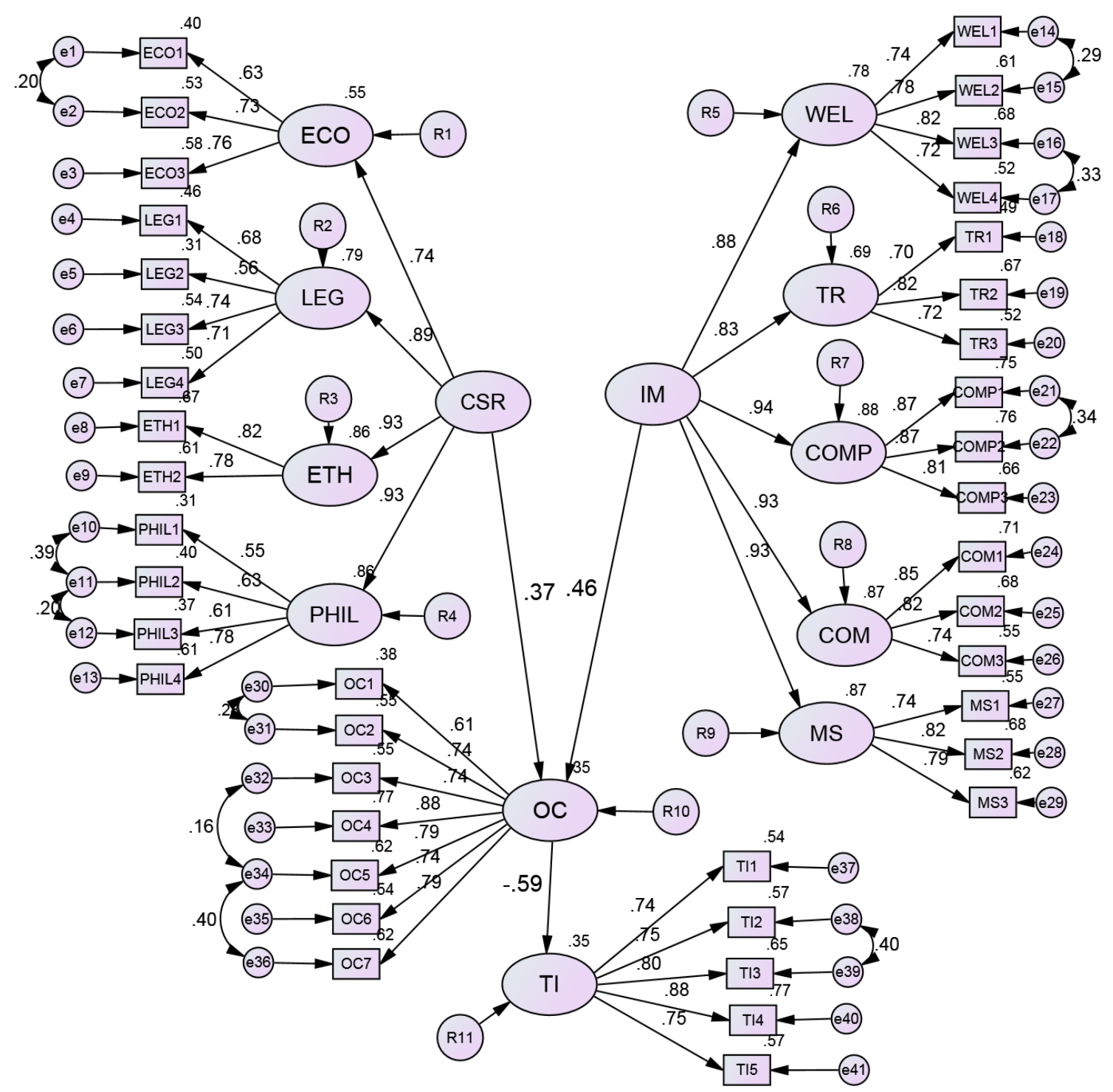

Figure 3. Standard regression coefficients in the general model of structural equations

\subsection{Testing the hypotheses}

In order to test the research hypotheses, weighted regressions of estimations are examined on the basis of which we may decide whether to reject or confirm research hypotheses. Weighted regressions of estimation are unstandardized coefficients obtained through maximum likelihood estimation. Unstandardized coefficient is a standard error value and a critical ratio which is calculated. A critical ratio shows the significance level of coefficients. Thus, if the critical ratio is greater than the absolute value of 1.96, then the path is significant at level 0.05 . The results of testing $\mathrm{H}_{1}$ to $\mathrm{H}_{3}$ are shown in Table 4 .

Table 4. Regression coefficients and significant relationships between variables (*** significance in level 0.01)

\begin{tabular}{|l|l|l|l|l|l|l|} 
Independent & Dependent & Path & Critica & Standar & Level of & Result \\
\hline
\end{tabular}




\begin{tabular}{|c|c|c|c|c|c|c|c|}
\hline & Variable & Variable & $\begin{array}{c}\text { Coefficien } \\
\mathrm{t}\end{array}$ & $\begin{array}{c}\mathrm{l} \\
\text { Ratio }\end{array}$ & $\mathrm{d}$ Error & $\begin{array}{c}\text { Significanc } \\
\mathrm{e}\end{array}$ & \\
\hline $\begin{array}{c}\mathrm{H} \\
1\end{array}$ & $\begin{array}{c}\text { Social } \\
\text { Responsibilit } \\
\mathrm{y}\end{array}$ & $\begin{array}{c}\text { Organization } \\
\text { al } \\
\text { Commitment }\end{array}$ & 0.503 & 6.163 & 0.081 & $* * *$ & $\begin{array}{c}\text { confirme } \\
\mathrm{d}\end{array}$ \\
\hline $\begin{array}{c}\mathrm{H} \\
2\end{array}$ & $\begin{array}{c}\text { Internal } \\
\text { Marketing }\end{array}$ & $\begin{array}{c}\text { Organization } \\
\text { al } \\
\text { Commitment }\end{array}$ & 0.486 & 7.499 & 0.064 & $* * *$ & $\begin{array}{c}\text { confirme } \\
\mathrm{d}\end{array}$ \\
\hline $\begin{array}{c}\mathrm{H} \\
3\end{array}$ & $\begin{array}{c}\text { Organization } \\
\text { al } \\
\text { Commitment }\end{array}$ & Turnover & -0.644 & -8.894 & 0.072 & $* * *$ & $\begin{array}{c}\text { confirme } \\
\mathrm{d}\end{array}$ \\
\hline
\end{tabular}

The results of Table 4. show a positive and significant effect of social responsibility on organizational commitment with a coefficient of 0.503 as well as a positive and significant effect of internal marketing on organizational commitment $(r=0.448 ; \mathrm{p}<0.05)$. Therefore, the first and second research hypotheses are confirmed. The results also show that organizational commitment has a negative and significant effect on employees' turnover intentions $(\mathrm{r}=$ 0.644; $\mathrm{p}<0.05)$. Therefore, the third research hypothesis is also confirmed. In order to test the fourth and fifth hypotheses of the study which investigate the mediating role of organizational commitment in the relationship between social responsibility and internal marketing considering employees' turnover intentions, the bootstrap method was used. The results are presented in Table 5.

Table 5. The full, indirect and direct effects of variables (*** There is no significance at level $0.01 \mathrm{~ns}$ )

\begin{tabular}{|c|c|c|c|c|c|}
\hline & $\begin{array}{c}\text { dependent variable - mediator } \\
\text { variable - independent } \\
\text { variable }\end{array}$ & $\begin{array}{c}\text { full } \\
\text { effect }\end{array}$ & $\begin{array}{c}\text { indirect } \\
\text { effect }\end{array}$ & $\begin{array}{c}\text { direct } \\
\text { effect }\end{array}$ & results \\
\hline $\mathrm{H}_{4}$ & $\begin{array}{c}\text { social responsibility - } \\
\text { organizational commitment }- \\
\text { turnover }\end{array}$ & $\begin{array}{c}-0.355 \\
* * *\end{array}$ & $\begin{array}{c}-0.347 \\
* * *\end{array}$ & $-0.003^{\text {ns }}$ & $\begin{array}{c}\text { full } \\
\text { mediation }\end{array}$ \\
\hline $\mathrm{H}_{5}$ & $\begin{array}{c}\text { internal marketing - } \\
\text { organizational commitment }- \\
\text { turnover }\end{array}$ & $\begin{array}{c}-0.259 \\
* * *\end{array}$ & $\begin{array}{c}-0.340 \\
* * *\end{array}$ & $0.08^{\mathrm{ns}}$ & $\begin{array}{c}\text { full } \\
\text { mediation }\end{array}$ \\
\hline
\end{tabular}

According to the results of Table 5., regression coefficient in full effect model is significant for the effect of both variables of social responsibility and internal marketing on turnover intention $(\mathrm{CL}=95 \%)$. Hence, mediation analysis is possible for both variables. Also, indirect paths for both social responsibility and internal marketing variables are statistically significant $(C L=95 \%)$; however, the direct path for both of these variables with turnover intention and in the presence of organizational commitment mediator variable is not meaningful. Therefore, according to bootstrapping technique, organizational commitment fully mediates the negative effect of social responsibility and internal marketing on turnover.

\section{Conclusion}

Since achieving higher levels of organizational commitment and lower levels of turnover intention are the key indices of organizational performance (Kim, Lee, 2016); therefore, the present research examined the effects of social responsibility and internal 
marketing on these critical indices in the field of banking. This research presented a model according to which employees' view of internal marketing and social responsibility of the organization has a significant and positive effect on organizational commitment of employees, which in turn decreases their turnover intention.

The current study confirms that social responsibility in banking sector consists of four distinct but related dimensions (i.e. economic, legal, ethical, and philanthropic responsibilities). This finding is consistent with Carroll's social performance model (1991 and 1998) (Carroll, 1991) which states that social responsibility is divided into four dimensions. Additionally, the findings related to $\mathrm{H} 1$ indicate a positive and significant relationship between social responsibility and organizational commitment in banking sector. Social responsibility programs are considered not only as one of the social requirements, but also as a way to address the needs and demands of employees in alignment with working in a more desirable organization (Lee, Song et. al, 2013). This phenomenon can be explained by the viewpoint of social identity theory (SIT). According to SIT, individuals tend to improve their perceptions and views regarding an organization based on the activities and identity of that organization (Peterson, 2004). This finding is consistent with the results of researches conducted by Vakola \& Nikolaou (2005), Peterson (2004), Prutina, (2016) and Kim et al. (2016).

The findings of current study also show that the five presented dimensions of internal marketing offered a thorough image of the multi-dimensional internal marketing concept in the banking industry. In addition, the results related to $\mathrm{H} 2$ show the positive and significant effect of internal marketing on organizational commitment and confirm the fact that implementation of internal marketing programs can be an effective strategy for increasing organizational commitment of employees. This finding is consistent with Kim et al. (2016).

Results obtained from testing $\mathrm{H} 3$ confirms that the presence of higher levels of organizational commitment among bank employees reduce their turnover intention. Researchers have shown that low levels of organizational commitment lead to a desire for searching new job opportunities, turnover intention and relocation. In other words, organizational commitment is negatively related to turnover intention. A wide range of empirical evidence in current literature shows that turnover intention adversely affects organizational commitment. These results are in line with the findings of Kim et al. (2016).

According to the results of $\mathrm{H} 4$ and $\mathrm{H} 5$ and given the fact that full and indirect effects of social responsibility and internal marketing on employees' turnover intention is significant, and taking into account that direct effect of social responsibility and internal marketing on emlpoyees' turnover intention with the presence of OC's mediator variable is not significant, organizational commitment plays the role of a complete mediator between social responsibility and turnover intention, as well as between internal marketing and turnover intention. This finding is in line with the findings of Kim et al. (2016).

Although some researches have examined and confirmed the effect of employees' organizational commitment on reducing turnover intention, so far, no research has empirically tested this effect through the use of social responsibility and internal marketing as the backgrounds of organizational commitment in banking sector. Hence, the findings of the current study shed more light on this area of research.

\section{References}

[1] Hom, P.W.\& Griffeth, R. (1995). Employee turnover. Cincinnati, Ohio: South western college publishing. 
[2] O'Reilly, C. (1989). Corporations, cults, and organizational culture: Lessons from Silicon Valley firms. Paper presented at the fortythird annual meeting of the Academy of Management, Dallas, TX.

[3] Hui, C. Lee, C \& Rousseau, D.M. (2004). Psychological contract and organizational citizenship behavior in China: Investigating generalizability and instrumentality. Journal of Applied Psychology. 89(2). 311-321.

[4] Dennis, J. C. (1995). The managerial implications of the learning organization: a new tool for internal marketing. Journal of Services Marketing. (9). 43-51.

[5] Hogg, G \& Carter, S. (2000). Employee attitudes and responses to internal marketing, internal marketing: directions for management. Richard J. Varey and Barbara R Lewis (Eds), Routledge, London. 24-109.

[6] Rafiq, M \& Ahmed, P.K. (2000). Advances in the IM concept: Definition, synthesis, and extension. Journal of Services Marketing. 14(6). 449-462.

[7] Cotton, John L \& Tuttle, Jeffrey M. (1986). Employee Turnover: A Meta-Analysis and Review with Implications for Research. The Academy of Management Review. 11(1). 55-70.

[8] Caruana, A \& Calleya, P. (1998). The effect of internal marketing on organizational commitment among retail bank managers. International Journal of Bank Marketing. 16(3). 108-116.

[9] MacLagan, P. (1999). Corporate social responsibility as a participative process. Business Ethics: A European Review, 8, 43-49.

[10] Bluedorn, Allen C. (1978). A Taxonomy of Turnover. The Academy of Management Review 3(3). 647-651.

[11] Kotler, Philip and Lee, Nancy. (2005). Corporate Social Responsibility - Doing the Most Good for Your Company and Your Cause. New Jersey: John Wiley and Sons.

[12] Holmes L, Watts R. (2000). Corporate Social Responsibility: Making Good Business Sense. World Business Council for Sustainable Development.

[13] Prutina, Z. (2016). The effect of corporate social responsibility on organizational commitment. Management. 21. 227-248.

[14] Ramos, W.J. (2015). Internal marketing (IM) dimensions and organizational commitment (OC) of Universal Banks' employees, Proceedings of the Second AsiaPacific Conference on Global Business, Economics, Finance and Social Sciences. 1012 .

[15] Vakola, M., \& Nikolaou, I. (2005). Attitudes towards organizational change: What is the role of employees' stress and commitment? Employee Relations. 27. 160-174.

[16] Peterson, D.K. (2004). The relationship between perceptions of corporate citizenship and organizational commitment. 43(3). 296-319.

[17] Kim, J. Song, H.J \& Lee, C.K. (2016). Effects of corporate social responsibility and internal marketing on organizational commitment and turnover intentions. International Journal of Hospitality Management. 55. 25-35.

[18] Berry L.L. (1981), "The employee as customers". Journal of Retail Banking. 3(3). 825.

[19] Varey, R. J. (1995). A model of internal marketing for building and sustaining a competitive service advantage. Journal of Marketing Management. 11(1). 25-40.

[20] Ismail, W \& Sheriff, N.M. (2017). The effect of internal marketing on organizational commitment: an empirical study in banking sector. Yemen. 15(1). 68-98. 
[21] Martinez Serna, M.D. Martinez, E.V. Guzman, G.M \& Carrilo, P.M. (2017). Impact of Internal Marketing, Organizational Commitment and Organizational Learning in the Innovation of SMES in Mexico. international Business Management. 11(2). 432-443.

[22] Varey, R.J \& Lewis, B. (1991). broadened conception of internal marketing. European Journal of Marketing. 33(9)/10 ,PP. 926-944.

[23] Berman, S. (1993). Social consciousness and the Development of Social Responsibility. Albany, NY: State University of New York Press.

[24] Mensah, H.K. Agyapong, A. \& Nuertey, D. (2017). The effect of corporate social responsibility on organizational commitment of employees of rural and community banks in ghana. Cogent Business \& Management. 4(1). 1-19.

[25] Ford, M. E. (1985). Social cognition and social competence in adolesence. developmental psychology. 18. 323-340.

[26] Fisscher, O \& Nijhof, A. (2005). Implication of business ethics for quality management. The TQM Magazine. 17(2). 150-160.

[27] Carroll, Archie B. (1991). The Pyramid of Corporate Social Responsibility: Toward the Moral Management of Organizational Stakeholders. Business Horizons.

[28] Lantos, GP. (2001). The boundaries of strategic corporate social responsibility. Journal of Consumer Marketing. 18(2). 595-630.

[29] Jamali, D \& Mirshak, R. (2006). Corporate social responsibility theory and practice in a developing country context, Journal of Business Ethics. 72. 243-262.

[30] Sheth, hell. (2006). Beyond the game: corporate social responsibility in the sports industry. A thesis submitted to the faculty of the University of North Carolina at Chapel Hill. 1-128.

[31] Gilligan, C. (1982). In a different voice. Cambridge. Harvard University Press.

[32] Lee, C.K. Song, H.J. Lee, H.M. Lee, S.\& Bernhard, B.J. (2013). The impact of CSR on casino employees' organizational trust, job satisfaction, and customer orientation: An empirical examination of responsible gambling strategies. Int.J. Hospitality Management. 33. 406-415. 